\title{
"The Infidel Piloting the True Believer": Thomas Cook and the Business of the Colonial Hajj
}

\author{
Michael Christopher Low
}

\section{The Pauper Pilgrim Question}

From the 186os until well into the twentieth century, the pilgrimage to Mecca emerged as a recurrent source of embarrassment for the Government of India. ${ }^{1}$ On the international stage, Indian pilgrims were characterized as the primary conduit for the globalization of epidemic diseases, most notably cholera, threatening not only the colonized in Asia but the colonizers at home in Europe. At the numerous international sanitary conferences held to address this threat, indigent pilgrims traveling from or through India were blamed as the most likely bearers of these deadly pathogens. Of particular concern was the significant number of pilgrims able to muster barely enough money to purchase a steamship ticket for their outgoing journey from Bombay to Jeddah. By the completion of the Hajj they would run out of cash, become stranded in Jeddah, and fall into a state of destitution. As one observer lamented, "It is a common sight after Haj to see people lying about the beach under the shade of the rocks, without money, without clothes, and without food or water, dying of disease and starvation." As a result of the pathogenic danger posed by this subset of pilgrims, states across Europe and the Islamic world were called upon to ensure that "beggars trusting to the charity of their richer brethren" were discouraged from undertaking "so long and expensive a business as the Haj."

1 For the most comprehensive treatment of the colonial Hajj from India, see John Slight, The British Empire and the Hajj, 1865-1956 (Cambridge: Harvard University Press, 2015). For parallel issues surrounding Southeast Asian pilgrims under British and Dutch jurisdiction, see also Eric Tagliacozzo, The Longest Journey: Southeast Asians and the Pilgrimage to Mecca (Oxford: Oxford University Press, 2013).

2 Thomas Cook Group Archives (hereafter TC), Peterborough, United Kingdom, Guardbook no. 27, Appendix no. 2, extract from the Times of India, 9 November 1885 in John Mason Cook to H. Luson, Under Secretary to the Government of India (Home Department-Sanitary), 1894 .

3 TC, Guardbook no. 27, “The Mecca Pilgrimage," The Excursionist, 26 March 1887. 
Until well into the 189os, however, British officials willfully denied that cholera was even communicable from person to person. On the one hand, Britain feared that such measures would affect the free flow of commerce between India and Europe. On the other hand, British opposition to quarantine measures and pilgrimage reform was equally related to their perception that any attempt to interfere with a fundamental Islamic tenet like the Hajj would constitute a violation of Queen Victoria's 1858 promise of non-interference in Indian religious affairs (given in the wake of the Great Rebellion) and incite another violent uprising among Indian Muslims. ${ }^{4}$

Despite both international quarantine efforts and a series of legislative reforms passed by the Government of India and local authorities in Bombay, by the early 188 os the plight of the "pauper pilgrim" appeared to be intensifying rather than abating. Each year the Indian press was flooded with more harrowing tales of pilgrimage-related scandals than the last. As pressure mounted on both the domestic and international fronts, the Government of India found itself caught between the need for dramatic reforms and their fear that any "direct" interference with the Hajj would be interpreted as an attack on religious freedom by Indian Muslims. In 1886, the Government of India succinctly described this dilemma in their correspondence with Thomas Cook and Son:

For several years past the attention of the Government of India has from time to time been directed to the desirability of alleviating, so far as is possible, the discomforts and sufferings experienced by Muhammadan pilgrims during the journey from India to the Hedjaz. The existence of these sufferings, more especially in the case of those of the poorer class of Muhammadans who undertake the pilgrimage, is an admitted fact; but the action taken with a view to afford relief has been necessarily of a restricted nature owing to the unwillingness felt by the Government to undertake any direct interference with what is considered to be a religious obligation by a large section of the Muhammadan community in India. ${ }^{5}$

4 Nicholas Dirks, Castes of Mind: Colonialism and the Making of Modern India (Princeton: Princeton University Press, 2001), 130.

5 Extract from the proceedings of the Government of India in the Home Department (Sanitary), 4 January 1886, TC, Guardbook no. 27, John Mason Cook, The Mecca Pilgrimage: Appointment by the Government of India of Thos. Cook \& Son as Agents for the Control of the movements of Mahomedan Pilgrims from all parts of India to Jeddah for Mecca, Medina, \&c., and Back (London, booklet printed for private circulation, 1886), 6. 
The most straightforward approach to the problem would have been to place conditions directly on the intending pilgrim by either requiring that they make a minimum deposit with the authorities to prove that they could afford the journey or purchase a roundtrip ticket. Indeed, this was the most common step taken by other states with large Muslim populations. However, the Government of India felt that a direct restriction on the mobility of poorer pilgrims might spark a violent response among Indian Muslims.

In an attempt to thread the needle between these seemingly irreconcilable concerns, the Government of India formulated a doctrine of "indirect" intervention. Rather than imposing restrictions on poor pilgrims, British officials attempted to reform the business of the Hajj. As a result, British reforms were primarily aimed at cleaning up the pilgrimage-shipping industry and its associated networks of ticketing brokers. On one hand, colonial administrators hoped that by tightening their regulation of the pilgrimage-shipping industry they could eliminate the worst instances of overcrowding and squalid conditions, which had been identified as one of the greatest factors contributing to the spread of cholera. On the other hand, by licensing ticketing brokers they hoped to provide pilgrims with a measure of consumer protection against aggressive touts, pricing scams, and coercive monopolies. This strategy also required ship owners to make major capital investments in their vessels in order to meet the new legal requirements. As the following letter to the Bombay Gazette, aptly written under the pen name "Oliver Twist," points out:

the effect of increasing the space [per pilgrim on board ships] would be simply that the Hadj would become a more expensive thing than it already is, and philanthropically disposed as the Government may be, it has no more right to legislate in that direction than it has to make it law that no-one shall go home except in a first-class P. \& o. steamer. ${ }^{6}$

As this critique of the government's strategy makes clear, requiring cleaner, larger, and better-equipped steamships would necessarily lead ship owners to raise ticket prices. Whether colonial officials admitted it or not, raising and fixing prices was the cornerstone of "indirect" intervention. If direct measures prohibiting poor pilgrims from setting out for Mecca were deemed too dangerous, the only other option was to raise the standards of travel in such a way that

6 Bombay Gazette, 31 August 1886, p. 14, quoted in Mark Harrison, "Quarantine, pilgrimage, and colonial trade: India 1866-1900," The Indian Economic and Social Review 29 (1992): 132. 
either eliminated unsanitary conditions or priced the poorest pilgrims out of the market altogether. ${ }^{7}$

Although poor pilgrims were certainly victims of this strategy, they were actually not the enemy in this equation. The true targets of the government's doctrine of "indirect" intervention were Muslim shipping interests and their associated brokerage networks. By the early 1880 s, the pilgrimage business had become thoroughly commercialized and competition was intense. From the perspective of the authorities, however, the competitive nature of the pilgrimage industry was merely evidence of its disorder. British officials came to view the entire complex of indigenous shipping interests and brokers as an inherently "unscrupulous" system, responsible for widespread and deliberate neglect of the government's evolving pilgrimage-shipping regulations. They were simultaneously the cause of and the primary obstacle to reform. Given their deep suspicion of Muslim ship owners and ticket brokers, the Government of India sought out a private partner willing to enforce its legislation and documentary procedures, raise the overall conditions of the industry, and wrest market share away from the existing competition. ${ }^{8}$

In January 1886, the Government of India passed a resolution making Thomas Cook and Son the official travel agent of the Hajj. After some five years of private correspondence between Cook's and high-ranking British officials and roughly two years of protracted negotiations and on-the-ground preparation, the firm was handed total control of all government functions related to the Hajj. ${ }^{9}$ As the conditions of the agreement between the two parties make clear, the Government of India attempted to foster a government-backed monopoly over the pilgrimage transportation industry for Thomas Cook and

7 Slight, The British Empire and the Hajj, 84-105; Oishi Takashi, "Friction and Rivalry over Pious Mobility: British Colonial Management of the Hajj and Reaction to It by Indian Muslims, 1870-1920," in Kuroki Hidemitsu, ed., The Influence of Human Mobility in Muslim Societies (London: Kegan Paul, 2003), 163-167; Radhika Singha, "Passport, ticket, and india-rubber stamp: 'The problem of the pauper pilgrim' in colonial India c. 1882-1925," in Ashwini Tambe and Harald Fischer-Tiné, eds., The Limits of British Colonial Control in South Asia: Spaces of disorder in the Indian Ocean region (London and New York: Routledge, 2009).

8 Slight, The British Empire and the Hajj, 98-105; Takashi, "Friction and Rivalry over Pious Mobility," 165-166; Singha, "Passport, ticket, and india-rubber stamp," 51-53.

9 TC, Guardbook no. 27, John Mason Cook, The Mecca Pilgrimage, 4-5; John Mason Cook to H. Luson, Under Secretary to the Government of India (Home Department-Sanitary), 1894, 3. See also Piers Brendon, Thomas Cook: 150 Years of Popular Tourism (London: Secker \& Warburg, 1991), 205-206; John Pudney, The Thomas Cook Story (London: Michael Joseph, 1953), 221-224. 
Son while simultaneously ceding responsibility for the regulation of that industry to the firm as well. In addition to the enormous operational latitude given to Thomas Cook and Son, they were also to be indemnified against any losses that they might incur while administering the Hajj. The effect of this ambitious privatization scheme was that Cook's employees were given the authority to act "precisely the same as though they were in service of the Government."10

At first glance, this experiment might appear to have been an odd pairing, doomed from its very inception. The Thomas Cook brand was and still is synonymous with the birth of modern travel. The firm is rightly considered to have almost single-handedly inaugurated the era of mass tourism by recognizing and satisfying the increasingly global appetites of Europe's growing middle classes. In India, Egypt, and Palestine, however, Cook's pioneered tours introducing better-off travelers, many of whom were accustomed to touring Europe independently, to "exotic" new locales, while carefully insulating them from the rigors, and often the realities, of the every-day life of the places they visited. ${ }^{11}$ For specialists of South Asian history Cook's reputation as that "lordly travel firm" has perhaps been doubly reinforced by the fact that Cook's operations in India were lauded both by the firm and by the highest echelons of British officialdom as a means for encouraging elite travel between England and India. ${ }^{12}$ In 1885 , the Prince of Wales appointed the company as the official travel agent for the upcoming Colonial and Indian Exhibition being held in London in connection with Queen Victoria's Golden Jubilee. The firm was charged with conducting both British notables and Indian princes to and from the festivities. ${ }^{13}$

In sharp contrast to these celebrated episodes of princely travel, the Hajj was viewed as an anachronistic, even dangerous, mode of travel, characterized

10 TC, Guardbook no. 27, John Mason Cook, The Mecca Pilgrimage, 5-6. For a more easily accessible copy of the agreement, see also The National Archives of the United Kingdom (hereafter TNA): Foreign Office (hereafter FO) 78/4094, reprinted in Alan de L. Rush, ed., Records of the Hajj: A Documentary History of the Pilgrimage to Mecca, vol. 3 (London: Archive Editions, 1993), 603.

11 F. Robert Hunter, "The Thomas Cook Archive for the Study of Tourism in North Africa and the Middle East," the Middle East Studies Association Bulletin 36, no. 2 (Winter 2003): 157-164; Donald Malcolm Reid, Whose Pharaohs?: Archaeology, Museums, and Egyptian National Identity from Napoleon to World War I (Berkeley: University of California Press, 2002), 89-92; Brendon, Thomas Cook, 120-140, 201-222; Pudney, The Thomas Cook Story, $181-231$.

12 Singha, "Passport, ticket, and india-rubber stamp," 52. See also Brendon, Thomas Cook, 201205; Pudney, The Thomas Cook Story, 221-222.

13 W. Fraser Rae, The Business of Travel: A Fifty Year's Record of Progress (London: Thomas Cook and Son, 1891), 208-219; Brendon, Thomas Cook, 205. 
by the mass movement of the poor and increasingly out of step with the emerging norms of modern international travel and tourism. ${ }^{14}$ Partly as result of the dissonance between Cook's reputation for elite travel and its role in the pilgrimage trade and partly because this novel experiment in colonial governance ultimately failed, more often than not, the firm's foray into the pilgrimage trade has been presented as a curious sideshow, an interesting piece of trivia, but not central to the story of Britain's administration of the Hajj and Muslim mobility.

Despite the ultimate failure of Thomas Cook's collaboration with the Government of India, the breathtaking ambition of this experiment offers a strong rebuttal to claims of British reluctance and inaction. Instead of thinking in terms of inactivity, this chapter explores how British officials in India framed pilgrimage reform as a question of direct regulation of pilgrims versus an indirect commercial intervention aimed at completely reconfiguring the system of guides, brokers, and shippers not just in India but in the Hijāz as well.

This essay also attempts to intervene by abandoning the notion that the pilgrimage market and regulatory system was solely a Bombay-centered struggle between the Government of India and poor pilgrims. As the firm quickly learned, the steamship Hajj had created an Indian Ocean-wide market place. ${ }^{15}$ The forces emanating from Jeddah, Mecca, Istanbul, and Southeast Asia were by no means trivial. By the time John Mason Cook's eldest son Frank first visited Jeddah in October 1886, the vast majority of pilgrimage traffic was already in the hands of a Hijāz-based cartel operating with the official backing of the Ottoman Governor and the Sharif of Mecca. ${ }^{16}$ This official monopoly organized a sophisticated profit-sharing scheme, tightly controlled the licensing of pilgrimage guides, and oversaw a vast patronage network. It also connected the local Hijāzi pilgrimage economy to the powerful Hadurami-Arab commercial diaspora in India, Singapore, and Java as well as to Dutch officials, shipping interests, and capital. ${ }^{17}$

\footnotetext{
14 Singha, "Passport, ticket, and india-rubber stamp," 50.

15 In addition to Frank Cook's notes from his preliminary research in India, Thomas Cook records also include two Hajj narratives compiled by Muslim employees, Jaffir Ali Najuf Ali (departing from Bombay) and Mohammed Abou-Elwa (the firm's Chief Egyptian Dragoman departed from Cairo), who were sent to scout the procedures associated with the pilgrimage in 1886. TC, Guardbook no. 27, Appendices 8-10, in John Mason Cook to H. Luson, Under Secretary to the Government of India (Home Department-Sanitary), 1894.

16 TC, Guardbook no. 27, Frank Cook, Jeddah to John Mason Cook, October 1886.

17 William Ochsenwald, Religion, Society, and the State in Arabia: The Hijaz under Ottoman
} 
By reframing the Thomas Cook project as a challenge not only to the pilgrimage-service industry in India, but also as a challenge to the pilgrimage monopoly in the Hijāz, this chapter seeks to reshape our understanding of the Hajj as an Indian Ocean-wide system. It also attempts to identify the political and commercial forces that proved so resilient in thwarting British and international regulation of the Hajj for so many decades. Thus, instead of focusing solely on passport regulations or the imposition of pre-paid roundtrip tickets aimed directly at poor pilgrims, which were never the Government of India's preferred way of reforming the Hajj, the chapter tackles the question of so-called indirect intervention. The Thomas Cook project was the embodiment of indirect intervention. And yet, it was far and away the Government of India's most aggressive attempt to deal with the seemingly untamable bundle of political, sanitary, and commercial crises swirling around the pre-World War I Hajj.

\section{Thomas Cook as the Agent of Empire: From the Midlands to Mecca, From the Pyramids to the Pilgrimage}

In 1841, Thomas Cook organized his first tour, a short railroad excursion for Baptist temperance supporters travelling to a rally just eleven miles away. Carrying his Baptist evangelism over into the tour business, shortly thereafter, Cook began offering "morally uplifting tours to customers as far down the social scale as possible." In 1851, Cook brought working-class men from the Midlands to London for the Great Exhibition. Four years later he would arrange his first European trip, leading a party across the English Channel to the International Exhibition in Paris. By 1864 he had led his first tour over the Alps and into Italy. ${ }^{18}$ As the Cook's empire grew so too did the firm's reputation for logistical innovation. Beginning in the late 1860 os and early 1870 . Cook's pioneered the use of novel new forms of credit, such as the hotel coupon, used for meals and accommodations instead of money, and the circular note, a kind of traveler's check. Perhaps most important of all was Cook's ability to offer fixed roundtrip fares at relatively low prices. ${ }^{19}$

Control, 1840-1908 (Columbus: Ohio State University Press, 1984), 101-106; Gülden Sarıyldız, Hicaz Karantina Teşkilatı (1865-1914) (Ankara: Türk Tarih Kurumu, 1996), 42.

18 Reid, Whose Pharaohs?, go.

19 Hunter, "The Thomas Cook Archive for the Study of Tourism in North Africa and the Middle East," 157. 


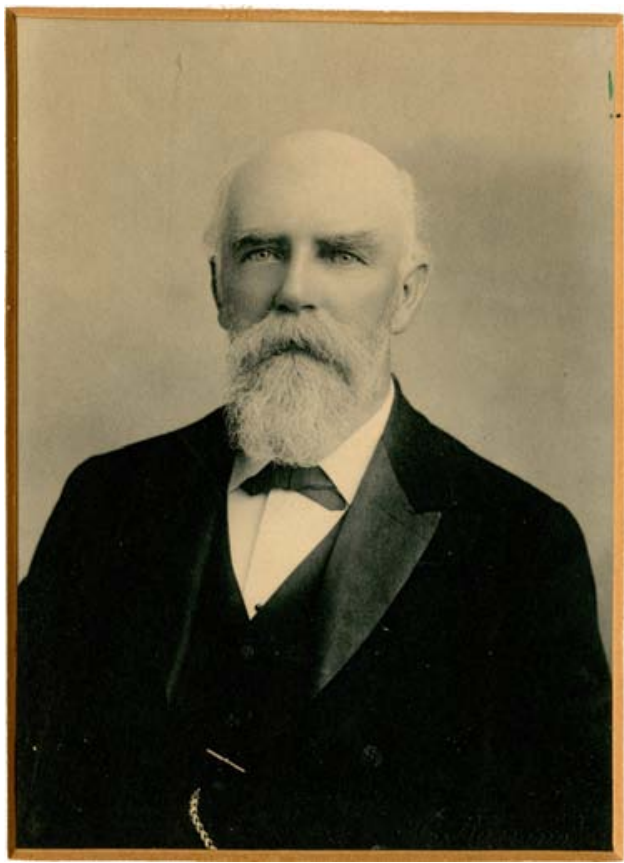

FIGURE 2.1

John Mason Cook, c. 1890 THOMAS COOK ARCHIVES, PETERBOROUGH, UNITED KINGDOM

By the late 1870s, Cook's had outgrown its humble beginnings in the Midlands and had taken its place at the commercial heart of the British Empire, Fleet Street in London. For many years Thomas Cook's son, John Mason Cook, had been an active junior partner in the family business, but by 1878 their partnership had become unmanageable. John Mason, the superior business mind among the two, forced his father into retirement. Having gained control of the company, John Mason ramped up both the firm's global expansion and its increasing role in the service of empire. ${ }^{20}$

Beginning in 1869, Cook's began a rapid expansion in Egypt and the rest of the Middle East. Egypt quickly became Cook's greatest success. There Cook established steamship service between Cairo and Aswan and in 1879 received a concession from the Egyptian government making him the sole provider of conveyance and mail services on the Nile. From Egypt, Cook's Middle Eastern operations branched out into Palestine and Syria, opening the Holy Land to a new breed of tourist-pilgrims armed with the Bible in one hand and their Murray's guidebooks in the other. ${ }^{21}$

20 Reid, Whose Pharaohs?, 9o; Pudney, The Thomas Cook Story, 214.

21 Hunter, "The Thomas Cook Archive for the Study of Tourism in North Africa and the Middle East," 157-164. 
By the 188 os, Thomas Cook agents had become so ubiquitous in capitals across the globe that the Daily Telegraph once styled them the "unofficial consuls" of Great Britain.22 In Egypt, it was even more difficult to distinguish between the power of Cook's tourist empire and that of the British Empire. In 1882, the British Government hired Cook's to convey Sir (later Lord) Garnet Wolseley and his staff to Egypt for the military campaign that would result in the British occupation of the country. Following the Battle of Tel al-Kabir, Cook's was once again called upon to organize the evacuation of the wounded. Cook's reputation as a master of imperial logistics was further enhanced when London again turned to John Mason Cook to organize a relief expedition to rescue General Charles Gordon from Khartoum. ${ }^{23}$ Although the mission was a failure, it was a massive undertaking. Cook arranged for the movement of 18,0oo troops, 40,000 tons of supplies, 40,000 tons of coal, and some 800 whaleboats from Tyneside to Egypt. The trip down the Nile required 27 steamers and 650 sailing boats to carry the troops and their supplies. In total, the entire operation would require another 5,00o local laborers. Having witnessed the enormous political and technological forces at Cook's command, one observer quipped: "The nominal suzerain of Egypt is the [Ottoman] Sultan; its real suzerain is Lord Cromer. Its nominal Governor is the Khedive; its real governor, for a touch of final comic opera, is Thomas Cook and Son."24

Although Cook's power in Egypt is well known among historians of that country, the situation in Indian historiography is much different. Thomas Cook and Son were relative latecomers to India. Their Indian operations have primarily been associated with elite travel and never achieved anything remotely close to the importance of their role in Egyptian society. Nevertheless, British officials in India had already taken notice of the auxiliary role that Cook's played in Britain's Egyptian and Sudanese military campaigns. As Robert Tignor points out, the British occupation of Egypt in 1882 brought an influx of British officials and experts trained in India. Drawing deeply upon their experiences in India, these men repeatedly grafted Indian institutions and methods of governance onto the Ottoman-Egyptian landscape they encountered. ${ }^{25}$ In a way, the Raj was trying to recreate this process in reverse. In this respect, it might

\footnotetext{
22 Daily Telegraph, 4 March 1899, quoted in Piers Brendon, Thomas Cook: 150 Years of Popular Tourism, 201.

23 Hunter, "The Thomas Cook Archive for the Study of Tourism in North Africa and the Middle East," 163.

24 G.W. Steevens, quoted in Pudney, The Thomas Cook Story, 212.

25 Robert Tignor, "The 'Indianization' of the Egyptian Administration under British Rule," American Historical Review 68, no. 3 (April, 1963), 637.
} 
be useful to expand our definition of Cook's work in Egypt and the Levant. Although the firm's core operations revolved around tours and vacations, it also exhibited many characteristics now associated with the privatization of government functions comparable to the kinds of transportation, communications, and military services provided by today's logistics firms and private defense contractors.

Cook's had a familiarity with the peoples and languages of the Arab-Ottoman world and had developed personal connections allowing the firm to navigate both the Khedival administration in Egypt as well as the Ottoman state in Palestine and Syria. In Palestine, Cook's had almost single-handedly created a new pilgrimage industry in Jerusalem and the lands of the Bible. In his correspondence with his eldest son, Frank Cook, who he had sent to scout the situation in Jeddah, John Mason could not resist drawing parallels between the Hajj and Cook's Palestine operations. John Mason instructed Frank to find out as much as he could about the disembarkation process at Jeddah, especially how the boatmen handled the pilgrims' luggage. As he reminded Frank, "In considering this bear in mind that at Jaffa a few years back we had precisely the same difficulty, even with first class passengers: the boatmen did precisely what the boatmen did at Jeddah, came aboard the steamers seized the luggage, pitched it into the boats, and the passengers had to follow whether they wished it or not."26 Just as the Cooks were confident that their experience in Palestine would carry over to India and the Hijāz, it would also appear that the Government of India had similar expectations. As the proceedings of the Home Department outlining the agreement between Cook's and the government proclaimed: "The extensive experience gained by Messrs. Cook and Son in connection with the requirements of schemes of a similar character and the considerable degree of success which has attended their operations, clearly pointed to that firm as peculiarly qualified to assist the Government ..."

In 1881, John Mason Cook made his first visit to India. At that time, he found that "India was a sealed book to tourists." Determined to open the country to mass tourism, Cook met with government and railway officials and began preparations for the opening of an office in Bombay. ${ }^{27}$ Although Cook later recalled that he had been made aware of the pilgrimage question by personal friends as early as 1876 , it was during his 1881 visit that he was first approached about intervening. The question was first raised by Colonel Staunton of the Government Railway Department in Bombay. As he recalled in 1894, "My reply was that when I had thoroughly organized our legitimate business, for which I

26 TC, Guardbook no. 27, Frank Cook, Jeddah, to John Mason Cook, October 1886.

27 Piers Brendon, Thomas Cook: 150 Years of Popular Tourism, 203. 
had gone to India, and put our general business arrangements into operation, I should then be prepared seriously to take up the pilgrimage question and do my best to meet his views." Although, Cook admitted that the subject had frequently come to his attention in the intervening years, his hands had been full with his commitments in Egypt.

It was not until October 1884 that he and the Government of India engaged in serious discussions about pilgrimage operations. In 1885, Cook received a personal letter from Lord Dufferin urging him to come to India to discuss the pilgrimage question further. In November 1885 , Cook set out for India. While en route he stopped in Cairo for a week. While there, Sir Henry DrummondWolff sent for him and inquired about his plans for the winter. Cook explained that he was off to India to discuss the Hajj with the Viceroy. Drummond-Wolff replied: "that is very singular, as that is the very thing that I, in the name of the Government, was going to ask you to do." He then handed over a bundle of telegrams exchanged between himself, the Viceroy, and Lord Randolph Churchill, then the Secretary of State for India. The correspondence revealed that while in Istanbul Drummond-Wolff had lobbied the Viceroy to take "some prompt and active measures" to reform the pilgrim trade. Lord Dufferin admitted that he could not carry out all of the measures suggested by Drummond-Wolff but expressed his eagerness to make improvements and promised to personally coordinate those reforms with John Mason Cook. Once Cook arrived in India, he met with the Viceroy and his chief advisors and by January 1886 the conditions of the agreement between Cook's and the Government of India had been agreed upon. ${ }^{28}$

\section{Breaking the Brokers: The Logic of "Indirect" Intervention}

Given that India was singled out as the source of epidemic cholera, both Britain and the Government of India found themselves awkwardly struggling against the tide of international opinion. During the height of the cholera era, from the 1860 os to 189 os, Britain vehemently opposed the international quarantine regulations and stricter passport regulations proposed by the rest of Europe and the Ottoman Empire. In 1886, W.H. Wilson, the Acting Commissioner of Police for Bombay, succinctly described the paralysis resulting from this dilemma:

The Acting Commissioner has the honour to report that a large number of Indian Pilgrims are no doubt very poor, and go to the Hedjaz not so

28 TC, Guardbook no. 27, John Mason Cook, The Mecca Pilgrimage, 5-6; John Mason Cook to H. Luson, Under Secretary to the Government of India (Home Department-Sanitary), 1894, p. 3. 


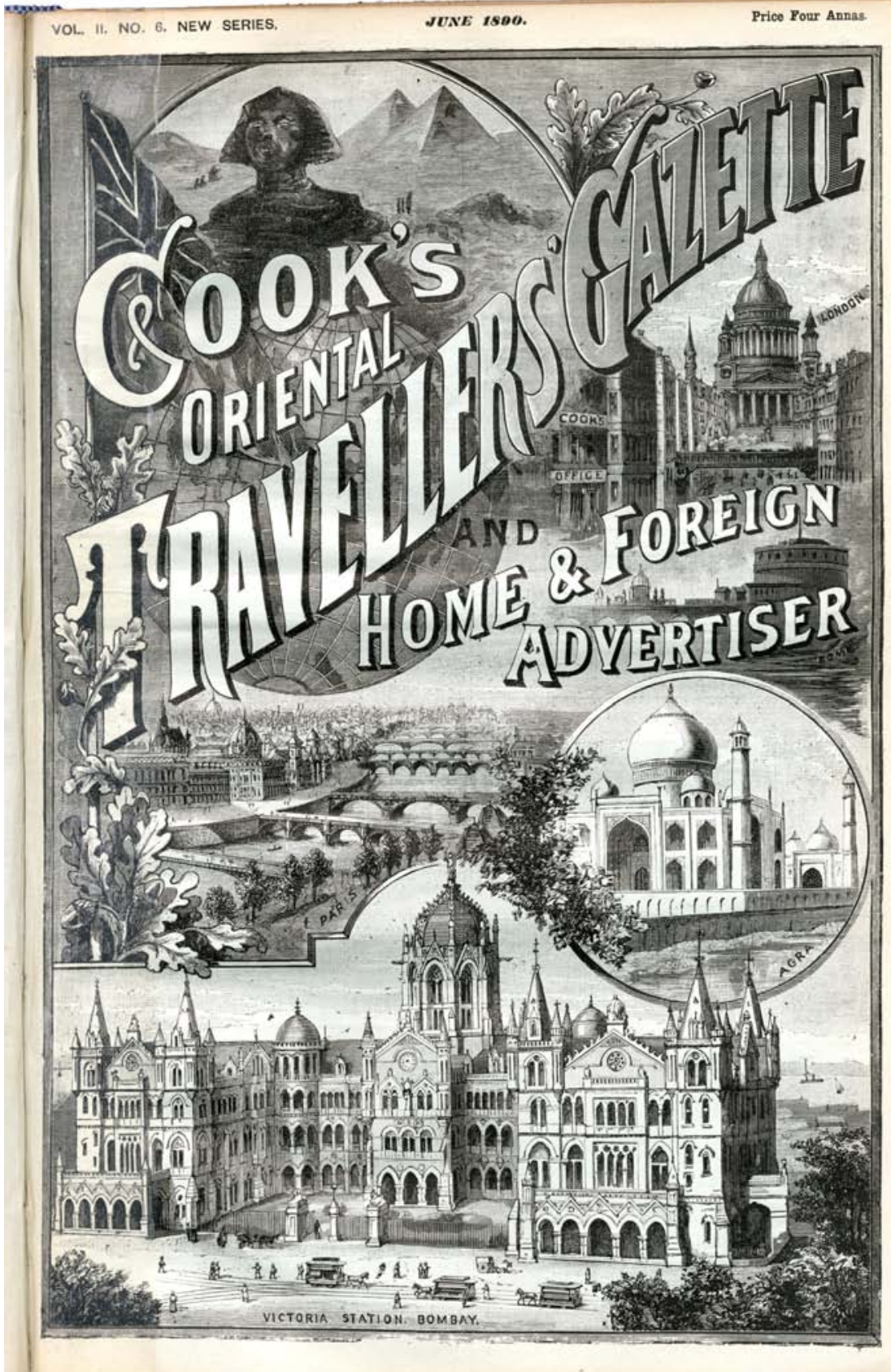

FIGURE 2.2 Cook's Oriental Travellers' Gazette and Home and Foreign Advertiser, 1890 THOMAS COOK ARCHIVES, PETERBOROUGH, UNITED KINGDOM 
much with the intention of maintaining themselves by begging, which they could do better in India, but on account of the sanctity of the place and with a feeling that if they die there they will go straight to Paradise. Some stay on waiting till death overtakes them, and others having no funds to return to India are forced to beg; but beyond warning them; it seems impossible to prevent them from going there. Any interference in this matter on the part of the British Government would be certainly taken as an interference in their religion. ${ }^{29}$

As a result of the Government of India's post-1858 guarantee of non-interference in religious matters, colonial administrators repeatedly refused to impose any form of "means test" to restrict the mobility of its poorer pilgrims. As the resolution outlining Thomas Cook \& Son's appointment explains, the general consensus among British officials was that "pilgrims should be required before proceeding on the voyage to deposit a sum of money sufficient to cover the cost of their return journey." Despite this admission "that such a regulation would prevent much misery and suffering," local authorities in Bombay were ardently "opposed to interference of this nature on the ground that it might be misunderstood and misinterpreted." As a result, instead of imposing a compulsory deposit system, the government decided to merely make a public notice in English, Hindustani, and Persian, warning that pilgrims should not undertake the journey without at least Rs. 300 in order to meet the expenses of the quarantine on Kamaran Island, the journey from Jeddah to Mecca and back, and still afford the cost of a return ticket to India. ${ }^{30}$

In this respect, the Government of India's timid response was an anomaly. Eventually the French in Algeria, the Dutch in Java, and Russian-controlled Muslim territories in Central Asia all adopted some form of compulsory passport or deposit system in order to regulate pious mobility. Later France, the Netherlands, and Russia adopted a mandatory system of return tickets in order to prevent indigent pilgrims from becoming stranded in the Hijāz without enough cash to pay for their passage home. Even more curious was the fact that other British possessions, including Egypt and the Straits Settlements, eventually adopted similar deposit and ticketing systems, while the Government of India refused. ${ }^{31}$

29 TNA: FO 78/4094, Report by Lieutenant-Colonel W.H. Wilson, Acting Commissioner of Police, Bombay, 3 April 1886, Records of the Hajj, vol. 3, p. 615 .

30 TC, Guardbook no. 27, John Mason Cook, The Mecca Pilgrimage, 6-8.

31 Singha, "Passport, ticket, and India-rubber stamp," 56. 
The advantages of this system were certainly not lost on British officials stationed in Jeddah. As Consul G. Beyts complained in an April 1875 report to his colleagues in Bombay:

I have to remark that at the termination of the pilgrim season a large number of British Indian subjects are left at Jeddah as vagrants and paupers, entirely destitute of the means of subsistence, many of these die from starvation; the passport system, adopted, would enable the authorities of the port at which passports are granted to ascertain whether the pilgrims who present themselves for these documents are amply provided with the funds for the purposes of performing their pilgrimage and returning to their countries. This precaution is always taken by the Dutch and French Governments, hence the reason why the subjects of those nations are not left in a state of poverty and destitution to die in the streets. ${ }^{32}$

For nearly three decades following the 1866 international sanitary conference, Britain declined to submit to any international agreements proposing stricter quarantine procedures, or to an integrated system of compulsory documentary and ticketing practices. Instead, the Government of India pursued an entirely separate package of reforms. As a result of their fear that fees attached to either passports or mandatory return tickets might be interpreted by Indian Muslims as government attempts to bar poorer Muslims from making the Hajj, the British sought a less direct path to pilgrim reform.

This doctrine of "indirect" reform was primarily aimed at regulating the pilgrimage's intertwined shipping and brokerage industries. The centerpiece of this legislation was the Native Passenger Ships Act of 1870 and its subsequent amendments in $1872,1876,1883$, and 1887 , culminating in the 1895 Pilgrim Ships Act. ${ }^{33}$ These regulations were primarily designed to restrict the number of passengers per vessel in the hopes that by alleviating instances of overcrowding the risk of cholera outbreaks would also be mitigated. These acts established clear limits on the maximum number of passengers according to each ship's registered or estimated tonnage. Likewise, they set guidelines gradually increasing the minimum superficial space per passenger according to their accommodation in the upper or lower decks. In addition to addressing the most basic question of overcrowding, these acts also stipulated mandatory

32 Fo 881/3079, Consul Beyts, Jeddah, to the Secretary to the Government of Bombay, 30 April 1875 .

Takashi, "Friction and Rivalry over Pious Mobility," 169-171. 
provisions for the safety and welfare of passengers and the shipping company and crew's obligations to its passengers. These included access to cooking fuel, clean water, proper ventilation and fresh air, clean latrines, and medical supplies. To ensure the compliance of shipping companies and in order to allow for easier surveillance of sick pilgrims during their journey, it was also required that ships carrying more than one hundred pilgrims have a qualified medical officer. ${ }^{34}$

With the 1883 Native Passengers Act, sailing vessels, which had long been in decline, were officially banned from the pilgrimage trade. While the prohibition on sailing vessels may have been a redundancy, the ban may be taken as indication of the long-term direction of British regulation. The most dramatic example of this process came when Britain, relenting to decades of international pressure and against the Government of India's vehement protests, signed the convention produced by the 1894 Paris international sanitary conference. The convention stipulated that the minimum space for each adult pilgrim be raised from 9 to 21 superficial feet. In order to meet the new international standards for superficial space, the Government of India's 1895 Pilgrim Ships Act required that all vessels be at least 500 tons and be able to achieve a speed of at least 8 knots under monsoon conditions. As government standards for shipboard fittings, anchors, cables, nautical instruments, safety equipment, overall tonnage, and speed during monsoon conditions were gradually raised, shipping companies were forced to either update their existing vessels or obtain newer ones. Although the government framed these reforms as either the products of international pressure or their own promotion of the best interests of pilgrims, scholars have generally underemphasized the extent to which this legislation was at least partially designed as a challenge to Muslim-owned shipping companies. While European shipping companies had little problem meeting the progressively tightening standards, Muslim shippers with comparatively limited access to capital and correspondingly older, less well-appointed, and smaller vessels struggled to comply with these regulations. During this period, Muslim shippers made several strategic adjustments. First, they found a niche in the market by catering to a lower-end clientele. Second, smaller individual or family-owned firms pooled their resources either to charter a ship for the pilgrimage season or to raise enough capital to stave off European competitors. By consolidating their resources, Muslim shippers were able to acquire

34 TC, Guardbook no. 27, John Mason Cook, The Mecca Pilgrimage, 6-7; TNA: FO 78/4093, Manual for the Guidance of Officers and Others concerned in the Red Sea Pilgrimage Traffic (Simla, India: Government Central Branch Press, 1884). 
larger, second-hand ships from European companies like Peninsular and Oriental and Lloyd's. ${ }^{35}$

At the same time, the Government of India also engaged in a parallel attack on Bombay and Calcutta's pilgrimage brokers. Ship owners depended on large networks of touts and petty brokers to attract business and sell tickets. Working for a commission, these brokers were repeatedly accused of fleecing pilgrims through a mixture of misinformation, intimidation, and bait-and-switch pricing scams. Worse still, they also conspired with ship owners to pack in more pilgrims per ship than was legally permitted. Here, The Times of India sketches a typical interaction between pilgrim and broker in Bombay:

... on arriving at the port, some by rail, some by local steamer, and others on foot, they are all more or less waylaid by what sailors call crimps, but who term themselves $\mathrm{Haj}$ brokers or runners, \&c., and any person who knows the ins and outs of Bombay, or any large seaport town, will understand that these individuals make all kinds of fair promises, \&c., to entice the pilgrims to their master's house, and once there, with their luggage of course, they cannot very well leave without buying a passage ticket from the master of the house. ${ }^{36}$

As this pattern became more familiar, the rapacious broker became the most ubiquitous villain in official descriptions of the pilgrimage trade. As one government official put it, pilgrims are "entirely at the mercy of a class of men very like the Liverpool crimps who charge them extortionately and rob them at all ends." 37

In an attempt to protect pilgrims from unscrupulous brokers, in 1883 Bombay passed the Pilgrim Protection Act, which required all brokers to obtain a license from the Bombay Police Commissioner. In conjunction with these licensing measures, a new position called the Protector of Pilgrims was created. Stationed at the port, this Muslim official was instructed to act as a special advocate,

35 Singha, "Passport, ticket, and India-rubber stamp," 51, 62-63; Takashi, "Friction and Rivalry over Pious Mobility," 171-172.

36 TC, Guardbook no. 27, Appendix no. 2, extract from the Times of India, 9 November 1885 in John Mason Cook to H. Luson, Under Secretary to the Government of India (Home Department-Sanitary), 1894.

TNA: FO 78/4094, A. Akin Higgins, Agent to Messrs. Thomas Cook and Son to the Secretary of the Political Department of the Government of India, Simla, 10 October 1884, in Records of the Hajj, vol. 3., 595 . 
providing information and assistance to intending pilgrims. ${ }^{38}$ In addition to the measures taken in Bombay, British officials also began to understand that they needed greater representation on the other side of the Indian Ocean. In 1878, Dr. Abdur Razzack was sent to accompany India's pilgrimage contingent for that year. Abdur Razzack was later appointed as the Muslim Vice-Consul of Jeddah in 1882. Two years later, additional Muslim Vice-Consuls were stationed at the Kamaran Island quarantine and the nearby Yemeni port of Hudayda. ${ }^{39}$

In spite of their nascent understanding of the role played by brokers in Bombay and their attempt to better represent pilgrims once they arrived in the Hijāz, British officials in India still failed to fully grasp the interconnected nature of the brokerage systems and their links to the highest levels of both Hijāzi society and the Ottoman and Sharifal administrations. In the Hijāz, pilgrimage guides known as the mutawwifin (known to Indians as mu'allims) exercised almost total control over the Hajj experience. Technically speaking, the term mutawwif refers to a guide for the circumambulation of the Ka'ba, known as the tawäf. In reality, their duties were in fact much broader. At the most basic level, they were responsible for guiding non-Arabic speaking foreigners through the required prayers and rituals of the Hajj. However, the mutawwifs were also responsible for shepherding their customers through every aspect of their stay in the Hijāz. From the moment that the pilgrims disembarked in Jeddah until the time they returned home they were under the constant supervision of their mutawwif. As soon as the pilgrims arrived in Jeddah, they were met by the mutawwif's wakil (agent). The wakil arranged for their camel transport and protection from marauding Bedouins and delivered them to their muțawwif in Mecca. Once in Mecca, the muțawwifs instructed the pilgrims on how to properly perform the rituals of the Hajj, acted as interpreter, arranged their lodging, and facilitated their purchases. ${ }^{40}$

In addition to their duties in the Hijāz, they also sent their deputies to India to advertise, recruit, and act as intermediaries between the Indian countryside, Bombay, and their operations in the Hijāz. Because the expertise of the

38 TC, Guardbook no. 27, Appendix no. 1, in John Mason Cook to H. Luson, Under Secretary to the Government of India (Home Department-Sanitary), 1894.

39 TNA: Fo $881 / 5155 x$, H. Hill to India Office, "History of the Quarantine and Cholera in Europe from 1878," April 1885, 7-8.

40 Fu'ād al-Ḥāmid 'Anqawī, Makkah: al-Hajj wa-al-țiwāfah (Saudi Arabia, 1994), 273-278, 299-303; Shakīb Arslān, al-Irtisamāt al-lịtāffi khāțir al-Hajj ilā aqdas mațāf (Cairo, 1931), 71-80; Snouck Hurgronje, Mekka in the Latter Part of the Nineteenth Century (Leiden: Brill, 1970), 24; Mai Yamani, Cradle of Islam: The Hijaz and the Quest for Identity in Saudi Arabia (London: I.B. Tauris, 2009), 42-45. 
muțawwifs and their local deputies was so specific to each language and region they served, generally membership in this professional guild was passed down from generation to generation. As a result, these agents possessed an enormous genealogical knowledge of who had or had not performed the Hajj. Working in concert with local maulvis, these recruiters not only sought to attract new clients but also to inspire more members of families that they had previously served to make the journey. As both Thomas Cook and the Government of India would eventually discover, regulating pilgrimage brokers in Bombay attacked only one link in a much larger chain. ${ }^{41}$

\section{The Rise and Precipitous Fall of the Thomas Cook Hajj, 1886-1893}

Despite repeated reform efforts, the 1880 s emerged as a decade of pilgrimagerelated scandals, exposing both the dark underbelly of the pilgrimage-shipping industry and the virtual paralysis of the government. Not surprisingly, however, poorer pilgrims continued to prefer the cheapest available fares. Thus, despite the government's increased regulation of the Hajj, there continued to be a strong correlation between inexpensive prices and the unsanitary and overcrowded conditions that the government had sought to eliminate in the first place. Because the government feared imposing any passport fees, mandatory deposits, or return tickets, they could not directly deter intending pilgrims regardless of how poor they might have been. The only avenue that remained available was to manipulate the price and quality of pilgrimage services by introducing an outside stimulus into the market. Since the government believed that Muslim shipping agents and brokers had been responsible for fostering the conditions that led to the pauperization of the Hajj, they sought out a shipping agent that could challenge and, if possible, eliminate the existing competition.

When the Government of India appointed Thomas Cook and Son in 1886, they entertained high hopes that the firm could pull off the logistical miracles in Bombay and Jeddah that it had so ably performed in Egypt, the Levant, and Sudan. Judging by the company's performance between 1886 and 1890, such optimism appears not to have been misplaced. The government expressed its satisfaction with the progress that Cook's shipboard representatives made in ensuring that the ships it chartered met all legal requirements

41 Michael Miller, “Pilgrims' Progress: The Business of the Hajj," Past and Present no. 191 (May 2006), 199 . 


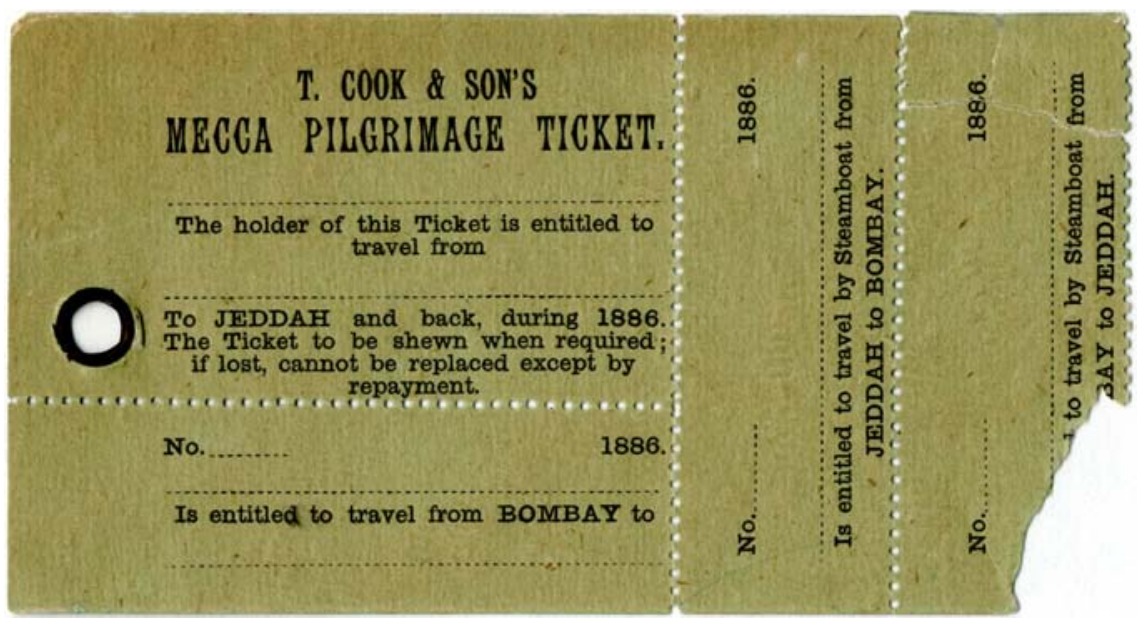

FIGURE 2.3 Thomas Cook Mecca Pilgrimage Ticket, 1886

THOMAS COOK ARCHIVES, PETERBOROUGH, UNITED KINGDOM

for medical surveillance and sanitation. Cook's introduced a fixed price system for the Bombay to Jeddah journey, allowing for no reduced-price tickets. The firm's dates of departure were fixed and publicized in advance and were generally observed. This allowed pilgrims making their way from inland destinations to purchase all-inclusive tickets for rail and steamship travel in advance. Even as the Cook's experiment soured in subsequent years, the government still claimed that Cook's introduction into the pilgrimage market had encouraged greater competition, forcing Muslim shipping agents to take measures to better their services, which had in turn raised the overall safety and comfort of the industry and led to a reduction in the opportunities for extortion. ${ }^{42}$

More importantly, with regard to the question of the "pauper pilgrim," the firm's indirect intervention did precisely what the government had wished to accomplish but feared doing itself. Cook's entrance into the pilgrimageshipping industry immediately altered the price structure, ticketing procedures, and flexible timetables that Muslim shipping agents, brokers, and poor pilgrims depended upon. Cook's set their fares at 30 rupees for the Bombay to Jeddah passage and 45 rupees for the roundtrip journey. In 1888 , the firm claimed that it was forced to raise the price 5 rupees because the previous price

42 TC, Guardbook no. 27, John Mason Cook to H. Luson, Under Secretary to the Government of India (Home Department-Sanitary), 1894, 5-6; Bombay Gazette, 16 January 1895. See also Takashi, "Friction and Rivalry over Pious Mobility," 165-167. 
proved unprofitable for the shippers with whom they had contracted. As John Mason Cook boasted in his final report to the government:

Taking as an average charge for a deck passage prior to the appointment of my firm at $5^{0}$ rupees each, which is a very low estimate, and taking as an average charge by my firm after their appointment upon the 35 rupee basis, and considering the abolition of charges previously in operation for embarkation at Bombay before the ships went into dock, and bearing in mind that through the reduced fares fixed by my firm the shippers in competition are compelled to reduce their fares to our basis, and frequently below it, I calculate that the saving to each individual pilgrim from these points alone may be very fairly based at from 25 to 30 rupees each ... ${ }^{43}$

While it is likely true that the firm's fixed price structure did technically lower average ticket prices from 50 to 35 rupees, Cook's claim that his operation had saved individual pilgrims 25 to 30 rupees each is difficult to accept. For wealthier pilgrims this may have actually been true since fixed fares placed limits on extortionist pricing schemes. However, fixed prices dramatically narrowed the options of poorer pilgrims. Poorer pilgrims preferred flexible timetables allowing them to either arrive at Bombay early to secure a cheap fare or to hold out until the last minute to take advantage of reduced or even free fares offered by Muslim shipping agents. Likewise, while the government discouraged extended stays in Bombay, for poor pilgrims this was often a critical stage in their journey. Bombay was often where pilgrims generated enough funds to either purchase a one-way ticket or where they replenished their funds after purchasing a ticket through labor, selling petty goods, or by begging. In other words, fixed prices and departure times impeded poor pilgrims' access to the kinds of charitable structures, sliding-scale pricing, and reduced or free fares they had come to rely upon. It is also very doubtful that these pilgrims would have opted to purchase more expensive roundtrip fares which would have eliminated the possibility of waiting for a last-minute reduced fare at the end of the Hajj season once shippers had sold enough full-price tickets to meet their operating expenses. ${ }^{44}$

Bearing these questions in mind, it is difficult to discern whether Cook's services were actually an attractive option for customers or whether the firm's

43 TC, Guardbook no. 27, John Mason Cook to H. Luson, Under Secretary to the Government of India (Home Department-Sanitary), 1894, 5-6.

44 Singha, "Passport, ticket, and india-rubber stamp," 52-53. 
gain in market share between 1887 and 1890 was simply a byproduct of the overwhelming government support that it received. It is also difficult to tell whether Cook's fixed-price system absorbed any appreciable share of the indigent population it aimed to eliminate or if the firm's increasing market share was merely a matter of attracting those pilgrims who could already afford fullprice fixed fares and roundtrip tickets. Leaving aside these unknowns, however, the firm's results were undeniable. In their first year of operation the firm was able to attract nearly 20 percent of the market. That figure rose steadily to 29.3 percent in $1888,38.6$ percent in 1889 , and peaked in 1890 at 44.5 percent. It appeared that Cook's was on its way to dominating the pilgrimage trade. 45

Despite the initial promise shown by the government's Thomas Cook project, these early gains proved illusory. In 1891, Cook's market share fell for the first time to 37.2 percent. That downward trend would continue until Cook's agreement with the government was terminated following the 1893 pilgrimage season when the firm failed to book even 10 percent of the total Indian pilgrim contingent.

It is difficult to say exactly what caused this precipitous collapse or to account for its timing. In the final years of their collaboration with the government, Thomas Cook and Son were accused of overbooking their ships. ${ }^{46}$ There were complaints that the firm had been unwilling to provide the necessary privacy for "respectable" women. ${ }^{47}$ Worse still, as many customers pointed out, the difference between ships chartered by Cook's and those captained by their competition was increasingly negligible. In fact, since Cook's contracted with companies like Hajji Cassum \& Co., customers began to take note of the fact that Cook's steamers often offered no advantages over other steamship offerings. ${ }^{48}$ Most damaging of all, however, was the outbreak of cholera on the Thomas Cook-chartered steamship, the Deccan, in 1890 . As a result of severe overcrowding on the Deccan some fifty pilgrims passed away during their quarantine on Kamaran Island. While in quarantine, the disease infected pilgrims traveling on the King Arthur and was subsequently spread to Jeddah and Mecca. ${ }^{49}$

45 TC, Guardbook no. 27, Extract from the Proceedings of the Government of India in the Home Department (Sanitary), Calcutta, 11 January 1895.

46 Harrison, "Quarantine, pilgrimage, and colonial trade," 133.

47 Singha, "Passport, ticket, and India-rubber stamp," 59.

48 Takashi, "Friction and Rivalry over Pious Mobility," 167.

49 Gülden Sarıyıldız and Ayşe Kavak, Halife II. Abdülhamid'in Hac Siyaseti: Dr. M. Şakir Bey'in 
While it is tempting to attribute Cook's plummeting market share in the years after 1890 to these embarrassing incidents, as John Mason Cook understood, the firm's problems were more systemic. In his final reports to the government in 1894, he identified two areas that were likely the sources of his troubles in Bombay. First, Cook chartered the appropriate number of steamships to accommodate the pilgrims it booked each year but did not own its own fleet. As Cook would complain once the project began to break down, "nothing short of a special service of steamers would enable them to compete successfully with the shippers who had controlled the pilgrimage traffic before they themselves had come on the scene." ${ }^{50}$ This leads to the obvious conclusion that although Muslim ship owners' market share had initially been damaged by the tremendous advantages conferred upon Thomas Cook by the government, in subsequent years they had made the necessary changes to compete, undercut Cook's prices, and successfully rallied to recapture their customers. In addition to owning their own ships, Muslim shipping agents could also still count on their superior networks of brokers to steer business away from Cook..$^{51}$

Despite Cook's confidence that he could not only reform the pilgrimage industry but also achieve profitability within three years, the profits never materialized. Even though the firm had been given almost total control of the government's documentary and regulatory apparatus and continued to receive an annual subsidy of $£ 1,000$, by 1891 "the firm expressed their conviction that the business could never be self-supporting, and they inquired whether the Government were prepared to guarantee them against actual monetary loss." In 1893, Cook's once again inquired as to whether or not the government intended to continue their annual subsidy. A report was called for by authorities in Bombay. The report revealed that despite all of the advantages of state sponsorship, the firm had failed to monopolize the pilgrimage-travel industry and marginalize indigenous Muslim shipping interests.

At peak of their intervention in 1890, the firm chartered four of the eleven steamships making the journey to the Hijāz, carrying 4,220 of the 9,953 pilgrims leaving from Bombay that year. Despite achieving approximately 45 percent

Hicaz Hatıraları (İstanbul: Timaş Yayınları, 2009), 6o-64, 297-298; Tc, Guardbook no. 27, Report of the Arrangments carried out by Thos. Cook and Son in connection with the movement of Pilgrims for the Hadj of 1890; John Mason Cook to H. Luson, Under Secretary to the Government of India (Home Department-Sanitary), 1894, 6.

$5^{1} \quad$ Singha, "Passport, ticket, and India-rubber stamp," 59. 
of the market share that year, in 1892-1893 their percentage dwindled to just 14 percent $(1,656$ out of 11,896$)$. In 1893, Thomas Cook and Son finally turned a profit, bringing in nearly Rs. 4,300. In order to achieve that modest gain, however, the percentage of pilgrims traveling on steamers chartered by the firm fell to an abysmal 9.5 percent, rendering the firm's services all but useless to the government. ${ }^{52}$ As The Pioneer reported in their January 1895 postmortem of the Thomas Cook project, "These figures proved that the experiment was a failure, and the Government had no other course than reluctantly to notify that the indemnity from loss could not be continued." ${ }^{\text {3 }}$

In November 1893, the agreement between Thomas Cook and Son and the Government came to an acrimonious end. In his final report to the government, John Mason Cook complained bitterly about the forces that had conspired against his firm:

I have shown clearly the result of the agreements to the benefit of the pilgrims, with the comparatively small cost to the Government of India, and I must be pardoned adding to this the facts that the agreement in question brought upon my firm. First, a certain amount of ill-feeling of certain officials of the Government of Bombay. Secondly, the strong enmity and opposition of all the steamboat proprietors and the mass of men who had been associated with them in the pilgrim trade, most of them being Mohomedans, who were making large profits out of their coreligionists; and Thirdly, the enmity and ill-will of a considerable number of Turkish officials at Cameran and the Hedjaz, and at Constantinople of all who participated in the large amount of money they were in the habit of taking from the pilgrims... With respect to the feeling of enmity brought about against my firm. Our representatives in India have clear proof that meetings were held by those interested in the pilgrim trade in Bombay at the instigation of Government officials, without any representative of my firm being invited to attend, and that complaints were concocted which your representatives could have proved perfectly groundless. I have also the fact that a Mohomedan member of the present Governor General's Council has been many years interested in the shipping of

$5^{2}$ TC, Guardbook no. 27, Extract from the Proceedings of the Government of India in the Home Department (Sanitary), Calcutta, 11 January 1895, 3-4.

53 TC, Guardbook no. 27, The Pioneer, January 1895. For similar coverage of the demise of the Thomas Cook experiment, see also The Indian Daily News, 14January 1895; and the Bombay Gazette, 16 January 1895 . 
Pilgrims, and through the arrangements of my firm, he with his colleagues have had to accept much lower rates for the conveyance of pilgrims ...54

Although one Muslim correspondent for the Bombay Gazette explained that the waning of Cook's "popularity was owing to the fact that a Mussulman has sentimental objections to being helped by "unbelievers" in his pilgrimage," as John Mason Cook's allegations make clear, it was not so much the pilgrims themselves but the complex web of Muslim shipping, brokerage, and political interests that Thomas Cook and Son had failed to conquer. ${ }^{55}$ The irony of Cook's accusations of secret meetings and collusion is glaring. If Cook's claims of secret plots against the firm were in fact true, it was poetic justice. Bombay's Muslim politicians and shipping interests had finally turned the tables on the firm and their government supporters.

While there might be an element of truth in Cook's accusations, it would be a mistake to simply accept his attempt to shift the blame for his failures to his Bombay competitors and their political alliances. If the animosity toward the firm in Bombay had been so pervasive, why did Cook's market share continue to grow for four years? The steady growth of Cook's share of the market over those years suggests that its government-backed operation in Bombay was able to break into the Indian side of the trade. However, this ignores the question of whether or not Cook's was equally successful in imposing its will on Ottoman officials in Istanbul, Jeddah, and Mecca. It also overlooks the degree to which India's Muslim shipping and brokerage industries were anchored to the Hijāz's pilgrimage guilds.

\section{Passport Optional?}

The most basic problem posed by the Ottoman administration in the Hijāz revolved around its policy toward passports. In 188o, the Ottoman government had demanded that all pilgrims carry a passport. As a result, the Government of India began issuing pilgrimage passports. At roughly the same time, however, Ottoman authorities were becoming increasingly aware that passports could also be manipulated by European consular officials to extend extraterritorial

54 TC, Guardbook no. 27, John Mason Cook to H. Luson, Under Secretary to the Government of India (Home Department-Sanitary), 1894, 7-8.

55 TC, Guardbook no. 27, Bombay Gazette, 16 January 1895. 
jurisdiction to their Muslim subjects making the Hajj. Under the Capitulations, Europeans were tried in separate mixed courts rather than in the regular Ottoman court system. However, European consular officials began to apply these same conditions to their Muslim subjects as well. As a result, Ottoman officials began to sharpen the legal distinction between Ottoman and nonOttoman Muslims in the Hijāz. Pilgrims from non-Ottoman lands who overstayed their welcome became a major concern for the Ottoman state during this period. Not only did their presence put strain on an already financiallystrapped province, many of them attempted to settle in the Hijāz. Whenever they ran into legal or financial difficulties, however, they would inevitably look to their former European governments to intercede on their behalf. Fearing that this would enhance the extraterritorial reach of European consulates in the Hijāz and foster divided loyalties, Ottoman officials banned non-Ottoman Muslims from owning property in $1882 .{ }^{56}$ Likewise, because passports made it easier for European states to claim jurisdiction over their Muslim subjects while on Hajj, the Ottoman state reversed its policy and its passport and visa requirements. ${ }^{57}$

As Abdur Razzack put it, Ottoman administrators on the ground readily admitted the impossibility of detaining "a person simply for not having a passport when he is dressed in the pilgrim's garb and sings out "Allah hooma labaik" (Oh God I am here)." ${ }^{58}$ In his capacities as Sultan-Caliph and Khädim al-Haramayn (Servitor of the Two Holy Places) Abdülhamid II could not afford to undermine his pan-Islamic prestige by turning away intending pilgrims landing in Jeddah. Thus, the maintenance of the Ottoman state's public image and the imposition of more rigorous forms of border control and biopolitical sovereignty were irreconcilably conflicted.

Despite this Ottoman reversal, the Government of India continued to issue pilgrim passports. However, the Cooks were disappointed to learn that the Government of India refused to make the passport compulsory. As the British Consulate in Jeddah made clear, if the Ottoman state was treating passports as optional, why should the Government of India make them mandatory? Sensing an opportunity, the Jeddah Consulate recommended that the Indian administration should issue pilgrimage passports "unconditionally" and "without any

56 Selim Deringil, The Well-Protected Domains: Ideology and the Legitimation of Power in the Ottoman Empire, 1876-19o9 (London: I.B. Tauris, 1998), 57-6o. Jeddah, 17 April 1883 . 
fee or deposit." By doing so, it was reasoned that "the entire odium of passport regulations" could be laid at the feet of the Sultan. ${ }^{59}$

As John Mason Cook bitterly complained in 1887 , "I always understood that every Pilgrim from ports of British India to the Hedjaz must take a passport." Yet, as his report for the 1887 pilgrimage season reveals, only 6,555 of the 9,389 pilgrims departing Indian ports were issued travel documents. ${ }^{60}$ Cook had expected that by making passports compulsory, even if they were given unconditionally, pilgrims would be funneled to his agents, ensuring that the firm would eventually gain a majority of the trade. However, without this critical element there was nothing to stop pilgrims from avoiding Thomas Cook-chartered ships altogether.

\section{An Indian Ocean Cartel: Monopolies, Muțawwifin, and Muslim Capital}

In addition to this critical flaw in the agreement between Cook's and the government, the Hijāzi side of the arrangements also proved considerably more difficult than John Mason Cook had originally expected. In 1887, the company touted its pilgrimage reforms in The Excursionist, the company's official publication, predicting that "in years to come the firm will secure concessions from the Turkish Government; in which case the world may witness the astounding spectacle of the Infidel piloting the True Believer through the dangers that beset the former's path to salvation."61 Judging from Cook's exuberance it would appear that he believed that he would be able to negotiate the same kind of exclusive concessions that he had so successfully concluded with the Khedival government in Egypt and the Viceroy in India. Cook vastly underestimated how sensitive Istanbul had become to the threat of European extraterritorial encroachment upon the Hijāz. An early indication of the frosty reception that awaited the Cooks in Jeddah came in October 1886 when the firm's representative in Istanbul attempted to get the International Sanitary Board to endorse their plans. After multiple attempts by the British Embassy and Dr. Patterson, the British delegate to the board, the Porte refused to provide Cook's with a let-

59 TNA: FO 195/1451, Lynedoch Moncrieff, Consul, Jeddah to Secretary to the Government of India, Foreign Department, 13 May 1883; Singha “Passport, ticket, and India-rubber stamp," 56 .

6o TC, Guardbook no. 27, Report of the Arrangements carried out by Thos. Cook and Son in connection with the movement of Pilgrims for the Hadj of 1887 .

61 TC, Guardbook no. 27, “The Mecca Pilgrimage," The Excursionist, 26 March 1887. 
ter of introduction. In the end, the central government replied that it would instruct the Governor of the Hijāz to assist the British Consul. However, they refused to work directly with Thomas Cook and Son. ${ }^{62}$

That same month, John Mason Cook sent his son Frank to Jeddah in order to plan the firm's operations in the Hijāz. Frank would quickly discover that their own arrangements in India were mere child's play in comparison with the massive state-sponsored monopoly on pilgrimage services being run from Jeddah. At the top of this pyramid sat the Ottoman Governor of the Hijāz, the Sharif of Mecca 'Awn al-Rafìq (r. 1882-1905), and a handful of the Hijāz's leading businessmen. Among them they controlled every aspect of the pilgrimage experience from steamships and boatmen to pilgrimage guides and camel brokers. With the organization of this system in 1883 , competition for transporting pilgrims was restricted, prices were rigged, and the resulting profits were shared among the members of the pool. Under this arrangement the Sharif was paid one Dutch guilder for every pilgrim. ${ }^{63}$ In return, the Sharif forced all of the pilgrimage guides and camel brokers to cooperate with the scheme. Owing to the restriction of competition, prices quickly doubled. The extra profits were divided as follows: 25 percent went to the Amir, 40 percent went to the guides and brokers, and the remaining 35 percent went to the founders of the monopoly. These included J.S. Oswald and his partner Hasan Johar (a wealthy Indian merchant), 'Umar al-Saqqāf (or Omar Alsagoff, a Ḥaḍramī shipping magnate), P.N. Van der Chijs (the Jeddah agent for the Ocean Steamship Company) and his business partner Yūsuf Kudzì (the British Consulate's translator), and J.A. Kruijt (the Dutch Consul). ${ }^{64}$

When Frank Cook arrived in Jeddah in 1886, the monopoly only targeted pilgrims from the Straits Settlements and Java. This did not mean that their power did not spill over into the management of Indian pilgrims. Indeed, even Frank Cook's brief tour of Jeddah was so completely orchestrated by the monopoly that the report to his father is almost comical. When he arrived at the docks he was met by none other than Yūsuf Kudzī. Kudzī and Hasan Johar were more than happy to show Cook the ropes. In what was likely an attempt to convince Cook that too much outside meddling would not be tolerated, they explained the monopoly system in great detail. Here, Cook

\footnotetext{
62 TC Guardbook no. 27, J. Caesar, Istanbul, to Messrs. Thomas Cook and Son, London, 1523 October 1886.

63 Michael Francis Laffan, Islamic Nationhood and Colonial Indonesia: The umma below the winds (London and New York: RoutledgeCurzon, 2003), 51-56.

64 Ochsenwald, Religion, Society, and the State in Arabia, 101-102; Sarıyldız, Hicaz Karantina Teşkilatı, 42 .
} 
learned why the Dutch Consulate was portrayed as the model of efficiency by Ottoman officials. ${ }^{65}$ In exchange for his cooperation in the monopoly, the Sharif was allowed to exclude all non-Ottoman citizens from the Javanese guild of the mutawwifin. ${ }^{66}$ In this way, he was able to exercise complete control over the pilgrimage guides without the prospect of Dutch or English interference. Each mutawwif was instructed to collect \$ 40 (currency unspecified) from each pilgrim, preferably before leaving Jeddah. This amount secured the pilgrim's passage home. The mutawwif would collect a commission of as much as $\$ 9$ and then turn over the remaining amount to the shipping agents for the pilgrim's return fare. As Frank Cook explained to his father:

One great cause of the business being in the hands of these three men is that many of the pilgrims pay part or all of their passage in bonds, to be worked out in plantation labour on their return, and some even get money advanced on these bonds. Mr. Omer Sagoff has estates in Singapore and can therefore use these bonds and no one else in Jeddah can. The bonds are supposed to be worth about $40 \%$ of their face value. It is calculated that one third of the Javanese pay for their passage, one third work it out on their return home, and one third give bonds then clear out on their return without redeeming them. ${ }^{67}$

Although Cook was made aware of this bonded labor or contract ticket scheme, initially he did not grasp the full extent of the ring. He appears to only have thought that the scheme involved Van der Chijs, al-Saqqāf, and Kudzī. While it is difficult to ascertain the extent to which Cook was being purposefully misled, at least one clue comes from his conversations with Hasan Johar. Despite his personal involvement and intimate knowledge of the ring, Johar coyly suggested that he "was certain that the Governor Genral of the Hedjaz, the Cherif, and the chief Motaouf [sic] were interested in the monopoly, by their readiness to give every assistance to the clique, but it is simply impossible to get proof of it." In the end, it is clear that Frank Cook understood that he was swimming in treacherous waters and was unsure whom to trust. Frank was especially concerned that the firm would not be able to handle return tickets without a local contact with the proper connections. ${ }^{68}$ Thus, in another almost absurd twist, despite learning of his role in the monopoly on Javanese and

65 TC, Guardbook no. 27, Frank Cook, Jeddah, to John Mason Cook, October 1886.

66 Ochsenwald, Religion, Society, and the State in Arabia, 101-102.

67 TC, Guardbook no. 27, Frank Cook, Jeddah, to John Mason Cook, October 1886.

68 TC, Guardbook no. 27, Frank Cook, Jeddah, to John Mason Cook, October 1886. While it is 
Malay pilgrims, Frank suggested to his father that Kudzī might be the firm's best prospect for a local booking agent. As a result, in February 1888, Kudzī agreed to take a 5 percent commission on all return tickets to India and became Cook's agent in Jeddah. ${ }^{69}$

Kudzī's involvement with Thomas Cook's operations in the Hijāz was a harbinger of things to come. That same year the Sharif attempted to extend the monopoly on Javanese and Malay pilgrims to Indian pilgrims. The Sharif instructed the head of the mutawwifin not to allow any Indian pilgrim to leave Mecca for Jeddah without having already booked their return ticket to India with one of the members of the monopoly. As a result, the price of return tickets increased by 60 percent. ${ }^{70}$ Not coincidentally, in 1888 and 1889, Indian Muslims holding return tickets issued by Thomas Cook and Son began to complain that upon their return from Mecca to Jeddah they were unable to obtain passage home. As 'Atā Mohammed, then the British ViceConsul at Hudayda, and Acting Consul Abdur Razzack in Jeddah reported, Kudzī and his associates were forcing Indian pilgrims to book their return tickets with steamship companies tied to the Java/Malay monopoly. Even more disturbingly, the Indian mutawwifs were forcing Indian pilgrims to purchase special Ottoman-printed Qurāns. If the pilgrims refused either to book their return tickets through the mutawwif's preferred steamer or to purchase their Qurāns, they were not allowed to secure a camel for the return to Jeddah.71

As it turned out, the Sharif had overreached. He had failed to include the new Ottoman Governor and J.S. Oswald. Oswald had left the Javanese/Malay monopoly and had even tried to break it. As a result of having overlooked these key figures, the Sharif exposed the monopoly to both the scrutiny of the British Consul and the Ottoman Governor. On 23 August 1889, the Governor arrested the Indian mutawwifin in Mecca. He also moved to dismantle the monopoly on Javanese and Malay pilgrims by abolishing the post of chief pilgrimage guide (shaykh al-mashäikh) for Javanese pilgrims. With the monopoly crashing down, Van der Chijs, then acting as the Consul for Sweden and Norway, committed

clear that Frank was being lied to by Ḥasan Johar, Moḥammed Abou-Elwa's report on the Hajj from that same month indicates that the company did eventually become aware of the Ottoman and Sharifal administrations' involvement in the monopoly. See Appendix no. 9, Translation from the Arabic Journal of Mohammed Abou-Elwa's Pilgrimage, Cairo to Meccah, Medinah, and back, 1886, in John Mason Cook to H. Luson, Under Secretary to the Government of India (Home Department-Sanitary), 1894.

69 TC, Guardbook no. 27, Yusuf Kudzī, Jeddah, to G. Dattari, Cairo, 8 February 1888.

70 Ochsenwald, Relgion, Society, and the State in Arabia, 102-103.

$71 \quad$ FO $78 / 4263$, "Pilgrim Traffic, 1888-1889." 
suicide and his company went out of business. Despite the Governor's apparent victory, the collapse of the monopoly would be brief. The Sharif, relying upon his connections in Istanbul, was able to lobby for the Governor's ouster. While the British Consul struggled mightily to have the monopoly dissolved, by 1896 the Sharif and his associates had worn down their opposition. Upon arriving in the Hijāz in 1896, the new British Consul G.P. Devey promptly announced that the monopoly was now part of the customary organization of the Hajj. In his opinion, "the pilgrims were not fleeced any more than tourists would be elsewhere in the world." 72

Although the Sharif was unable to fully integrate Indian pilgrims into the Java/Malay shipping monopoly, it is clear that Indian pilgrims were being actively coerced to book return tickets with firms connected to his cartel. It is also evident that Yusuf Kudzìs five percent commission on Cook's tickets was not enough to buy the cooperation of the Sharif and his cartel. ${ }^{73}$

Regardless of whether Indian pilgrims fared better than their Javanese or Malay coreligionists, they were still vulnerable to other pressures. Ever since Sharif 'Awn al-Rafiq's appointment in 1882, he was determined to tighten his control over the mutawwifin guild system. Prior to his tenure as Sharif, theoretically anyone had been free to purchase a lifetime license for a particular region. From the mid-188os onward 'Awn al-Rafīq began to exclude non-Ottoman citizens, especially those from Java, the Straits Settlements, and India, from being appointed as mutawwifs. The Sharif also instituted a new licensing procedure, known as the taqrir system. Under this system individual mutawwifs were no longer free to compete for pilgrims from a particular region. Instead, 'Awn alRafiq began auctioning licenses for control of each region. Also, rather than issuing lifetime licenses, the Sharif forced the shaykhs competing for control over their respective regions to renew their claims whenever the Amir's administration declared a new round of bids. As the bids for control of the Java, Malay, and Indian divisions of the guild became more expensive, it became necessary for the mutawwifs to pass the cost on to the pilgrims, leading to inflated prices for boats, housing, camels, tents, and almost every other necessity. ${ }^{74}$ As Thomas Cook's Chief Egyptian Dragoman Moḥammed Abou-Elwa aptly put it

72 Ochsenwald, Relgion, Society, and the State in Arabia, 102-103.

73 TC, Guardbook no. 27, Yusuf Kudzi, Jeddah, to G. Dattari, Cairo, 8 February 1888.

74 'Anqawī, Makkah: al-Hajj wa-al-țiwāfah, 280-285, 330-333; Mary Byrne McDonnell, "The Conduct of Hajj from Malaysia and Its Socio-Economic Impact on Malay Society: A Descriptive and Analytical Study, 1860-1981," vol. 1. (Ph.D. diss., Columbia University, 1986), $5^{8-60 .}$ 
in his 1886 report on the Hajj, "A pilgrim in the Hedjaz lands is just as grass and a nice piece of meat everyone likes to take a piece of it."75

\section{Conclusion}

While it is impossible to know the extent to which the Sharif of Mecca's stranglehold on the mutawwifin inflated prices for Indian pilgrims, this episode underscores the extent to which Cook's and their clients were at a distinct disadvantage on both sides of the Indian Ocean. In Bombay, Cook's could not rely on local brokers to steer business to them. On the one hand, the Government of India's attempts to marginalize brokers made them natural enemies of the firm. On the other hand, these brokers were also connected to Hijāzi-based muțawwifs and their wakils. On the Hijāzi side, Cook's could neither operate outside of Jeddah, nor could they promise any assistance in securing the services of the mutawwifs or their associated camel drivers. These aspects of the pilgrimage would remain under the control of the Sharif.

Although Thomas Cook and Son managed to avoid being completely shut out of the Hijāz pilgrimage trade, their involvement with Yūsuf Kudzī hints at the all-encompassing nature of the Sharif's monopoly. It is fitting that the Government of India's attempt to impose its own state-sponsored control over the Indian pilgrimage-shipping industry was defeated by a parallel cartel scheme anchored on the other side of the Indian Ocean. It is also highly likely that the firm's inability to break the Hijāzi cartel played a major role in pushing prospective pilgrims back into the arms of the reorganized Muslim shippers and brokers in Bombay. Thus, in the end, Cook's could neither defeat the Sharif's monopoly, Muslim capital in Bombay, nor the vast networks of the mutawwifin that held the two sides of the Hajj industry together.

Ultimately, as John Mason Cook came to lament, despite the Government of India's desire to ameliorate the plight of indigent pilgrims, its hesitancy to impose mandatory passport controls linked to roundtrip tickets completely undercut Thomas Cook's advantage as the official agent of the Indian Hajj. As John Slight points out, "The interplay between destitute pilgrims and British imperial prestige occurred within the broader context of intense imperial rivalry among the Ottoman, British, Dutch, and French empires on the issue of

75 TC, Guardbook no. 27, Appendix no. 9, Translation from the Arabic Journal of Mohammed Abou-Elwa's Pilgrimage, Cairo to Meccah, Medinah, and back, 1886, in John Mason Cook to H. Luson, Under Secretary to the Government of India (Home Department-Sanitary), 1894. 
the Hajj and control of the Red Sea as a strategic corridor, which in turn was part of a larger competition for power and resources that extended far beyond."76 Indeed, especially for the British and Ottoman empires this was a pan-Islamic struggle for loyalty and legitimacy as imperial stewards and protectors of the global Muslim community. Thus, despite both empires' obvious interests in circumscribing the mobility of indigent pilgrims, imposing more intrusive forms of surveillance, and erecting tighter border and documentary controls, neither side dared to risk being accused of authoring regulations directly prohibiting Muslims from fulfilling their sacred pilgrim duties. This powerful dynamic would prove to be one of the most intractable paradoxes of the colonial-era Hajj. This basic tension was both the source of the British Empire's chimerical strategy of indirect intervention as well as its fatal flaw.

Despite the failure of the Thomas Cook experiment, it was a harbinger of things to come. Efforts to ameliorate the sufferings of India's destitute pilgrims were a consistent feature of the British Empire's management of the Hajj from the 1870 s until the era of decolonization. In many respects, Thomas Cook's effort to bind together mandatory passport controls with a roundtrip-ticket system presaged the kind of reforms achieved after World War I and the demise of the British Empire's rivalry with the Ottoman Caliphate. Between 1923 and 1926, revisions to the Indian Merchant Shipping Act finally took the steps that the Thomas Cook project had anticipated decades earlier. These new regulations made it obligatory for any Indian or foreign pilgrim sailing from an Indian port to purchase a return ticket or make a minimum deposit with the government prior to embarkation. Those pilgrims purchasing the lowest class of pilgrimage steamship tickets were made to produce a return ticket in order to get an embarkation ticket to board their Jeddah-bound ship. Shipping companies once again partnered with the Bombay police in order to ensure that only intending pilgrims whose passports showed that they had deposited 60 rupees would be issued tickets to Jeddah. Similarly, in Jeddah, after the conclusion of the Hajj, pilgrims were made to provide proof of their deposit to the shipping companies in order to receive their return tickets. ${ }^{77}$ The postwar administration of the Hajj was no longer an Anglo-Ottoman condominium. After nearly a half century, the laws governing Muslim pious mobility had became a wholly colonial affair. And at least for a time, the British Empire did precisely what it had so often proclaimed it would not do. It came to directly legislate who could and could not make the Hajj.

76 Slight, The British Empire and the Hajj, 104.

77 Ibid., 214. 


\section{References}

\section{Archival Sources}

The National Archives of the United Kingdom (TNA), Foreign Office (FO) Thomas Cook Group Archives (TC), "The Mecca Pilgrimages, 1886-1894"

\section{Published Sources}

'Anqawī, Fu'ād al-Hāmid. Makkah: al-Hajj wa-al- țiwāfah. Saudi Arabia, 1994.

Arslān, Shakīb. al-Irtisamāt al-lìṭāffí khāṭir al-Hajj ilā aqdas mațāf. Cairo: Matba’at alManar, 1931.

Brendon, Piers. Thomas Cook: 150 Years of Popular Tourism. London: Secker \& Warburg, 1991.

de L. Rush, Alan, ed. Records of the Hajj: A Documentary History of the Pilgrimage to Mecca. 10 vols. London: Archive Editions, 1993.

Deringil, Selim. The Well-Protected Domains: Ideology and the Legitimation of Power in the Ottoman Empire, 1876-19o9. London: I.B. Tauris, 1998.

Dirks, Nicholas. Castes of Mind: Colonialism and the Making of Modern India. Princeton: Princeton University Press, 2001.

Drummond-Wolff, Sir Henry. Rambling Recollections. London: MacMillan, 1908.

Harrison, Mark. "Quarantine, pilgrimage, and colonial trade: India 1866-1900." The Indian Economic and Social Review 29 (1992): 117-144.

Hunter, Robert F. "The Thomas Cook Archive for the Study of Tourism in North Africa and the Middle East." Middle East Studies Association Bulletin 36, no. 2 (2003): 157164 .

Hurgronje, Snouck. Mekka in the Latter Part of the Nineteenth Century. Leiden: Brill, 1970. Laffan, Michael Francis. Islamic Nationhood and Colonial Indonesia: The umma below the winds. London and New York: RoutledgeCurzon, 2003.

MacDonnell, Mary Byrne. "The Conduct of Hajj from Malaysia and Its Socio-Economic Impact on Malay Society: A Descriptive and Analytical Study, 1860-1981." PhD diss., Columbia University, 1986.

Manual for the Guidance of Officers and Others concerned in the Red Sea Pilgrimage Traffic. Simla, India: Government Central Branch Press, 1884.

Miller, Michael. "Pilgrims' Progress: The Business of the Hajj," Past and Present 191, no. 1 (2006): 189-228.

Ochsenwald, William. Religion, Society, and the State in Arabia: The Hijaz under Ottoman Control, 1840-1908. Columbus: Ohio State University, 1984.

Pudney, John. The Thomas Cook Story. London: Michael Joseph, 1953.

Rae, W. Fraser. The Business of Travel: A Fifty Year's Record of Progress. London: Thomas Cook and Son, 1891.

Reid, Donald Malcolm. Whose Pharaohs?: Archaeology, Museums, and Egyptian Na- 
tional Identity from Napoleon to World War I. Berkeley: University of California Press, 2002.

Sarıyldız, Gülden. Hicaz Karantina Teşkilatı, 1865-1914. Ankara: Türk Tarih Kurumu, 1996.

Sarıyıldız, Gülden and Ayşe Kavak, eds. Halife II. Abdülhamid'in Hac Siyaseti: Dr. M. Şakir Bey'in Hicaz Hatıraları. İstanbul: Timaş Yayınları, 2009.

Singha, Radhika. "Passport, ticket, and India_-rubber stamp: "the problem of the pauper pilgrim" in colonial India ca. 1882-1925." In Fischer-Tine, Harald, and Ashwini Tambe, eds. The Limits of British Colonial Control in South Asia, Spaces of Disorder in the Indian Ocean Region. London: Routledge, 2008.

Slight, John. The British Empire and the Hajj, 1865-1956. Cambridge: Harvard University Press, 2015.

Tagliacozzo, Eric. The Longest Journey: Southeast Asians and the Pilgrimage to Mecca. Oxford: Oxford University Press, 2013.

Takashi, Oishi. "Friction and Rivalry over Pious Mobility: British Colonial Management of the Hajj and Reaction to It by Indian Muslims, 1870-1920." In Kuroki Hidemitsu, ed. The Influence of Human Mobility in Muslim Societies. London: Kegan Paul, 2003.

Tignor, Robert. "The 'Indianization' of the Egyptian Administration under British Rule," American Historical Review 68, no. 3 (1963): 636-661.

Yamani, Mai. Cradle of Islam: The Hijaz and the Quest for Identity in Saudi Arabia. London: I.B. Tauris, 2009. 